Article

\title{
Adaptation of Innovations in the IT Industry in Poland: The Impact of Selected Internal Communication Factors
}

\author{
Józef Ober *(D) and Anna Kochmańska (D) \\ Department of Applied Social Sciences, Faculty of Organization and Management, Silesian University of \\ Technology, Roosevelta Str. 26-28, 41-800 Zabrze, Poland; Anna.Kochmanska@polsl.pl \\ * Correspondence: Jozef.Ober@polsl.pl; Tel.: +48-322-777-323
}

check for

updates

Citation: Ober, J.; Kochmańska, A. Adaptation of Innovations in the IT Industry in Poland: The Impact of Selected Internal Communication Factors. Sustainability 2022, 14, 140. https://doi.org/10.3390/su14010140

Academic Editors: Lorenzo Ardito, Vito Albino, Achille Claudio Garavelli and Pierpaolo Pontrandolfo

Received: 4 December 2021

Accepted: 21 December 2021

Published: 23 December 2021

Publisher's Note: MDPI stays neutral with regard to jurisdictional claims in published maps and institutional affiliations.

Copyright: (c) 2021 by the authors. Licensee MDPI, Basel, Switzerland. This article is an open access article distributed under the terms and conditions of the Creative Commons Attribution (CC BY) license (https:// creativecommons.org/licenses/by/ $4.0 /)$.

\begin{abstract}
Adaptation of innovations by employees, especially in hi-tech industries, is very important from the perspectives of both implementing new technologies and maintaining competitiveness in today's dynamic market. The paper analyzes selected internal communication factors in terms of their potential impacts on the adaptation of innovations in information technology (IT) companies in Poland. These factors were determined on the basis of a literature analysis, opinions of panel participants (experts), and pilot studies that have been conducted. The undoubtedly innovative element is the study of the impact of the above-mentioned factors on the individual stages of innovation. The aim of the study was to identify and assess the perception of the influence of selected factors related to internal communication in a company on the adaptation of innovation by employees of the IT industry in Poland, taking into account the different stages of the implementation. The hypothesis of the study was that selected internal communication factors have different effects on innovation adoption at different stages of the innovation process. The study combined expert opinions and a literature analysis with a diagnostic survey (questionnaire) and a statistical analysis. The questionnaire survey allowed the examination of the opinions of the respondents about the impacts of 12 factors related to internal communication in the company on the adaptation of innovation. The results of the study confirmed the hypothesis and allowed the formulation of theoretical and practical conclusions that can be applied when introducing innovations.
\end{abstract}

Keywords: adaptation of innovations; innovation adoption; innovations; innovativeness; internal communication

\section{Introduction}

If companies are to grow and remain competitive in the market, they need new ideas and innovative solutions. In the era of the COVID-19 pandemic, the implementation of innovation on the organizational ground is particularly challenging, especially since it has had a negative impact not only on the economy, but also on social welfare systems and interpersonal relationships, resulting in an unprecedented global crisis [1]. As of early 2020, COVID-19 spread around the world at an alarming rate, also causing many threats to the sustainability of the business sector [2]. Moreover, this new and unusual situation creates an environment of uncertainty for employees themselves, adversely affecting their performance [3]. Therefore, such an unexpected pandemic reality has prompted many companies to change their approaches to business management and to focus on the adaptation of innovations by employees.

It is worth noting that the success associated with innovation depends on corporate decision makers. They act as facilitators of innovation, while their decisions are undoubtedly influenced by psychological factors that have not been fully explored. Therefore, understanding these factors is crucial for organizations that want to boost the adoption of new technologies, as well as for innovators, who face numerous barriers when introducing new products into the industrial market [4,5]. 
By analyzing the literature on the subject, it can be concluded that there are diverse definitions of innovation. The approaches to innovation presented below belong to different perspectives on innovation and guide research in this area. Innovation can be defined as a basic activity for development and the productivity of any economic activity [6,7]. Another approach indicates that innovation is more than the introduction of new products and services; namely, it is closely aligned with business strategy, covering all types of business activities [8]. Referring to the current situation, it can also be mentioned that innovation is seen as a key aspect of economic recovery during and after the ongoing pandemic period [9]. Innovation is also considered as a source of competitive advantage [10]. Innovation systems, on the other hand, are defined as complex systems that evolve in a non-linear manner, giving them unique properties that distinguish them from other systems [11]. Consequently, many types of innovations can be identified. Among them, it is worth mentioning the so-called open innovation [12], which is an important phenomenon in a global market where knowledge is diffused and individual companies no longer have a monopoly on the best talent. As companies are increasingly looking for innovative ideas and external solutions, the obvious problem is that of doing this in an efficient way [13]. Green innovations are also becoming very popular. Their emergence is related to the desire of companies for sustainable development [14,15], and it means the implementation of innovative, environmentally friendly production methods and processes that reduce the negative impacts of company activities on their external environment [16]. Innovativeness, on the other hand, focuses on innovation as a result of a company's innovative activities [17]. It reflects a firm's tendency to adapt new technologies or practices and go beyond the current state of the art [18].

Over the past few years, many studies have been conducted that focused on those characteristics of organizations that affect the introduction of innovations in a favorable or unfavorable way, the impact of informal communication on the innovation process, and the conditions for the implementation of innovative projects in organizations [19]. Despite the fact that companies are aware of the importance of communication when creating differentiated innovations, it is difficult for them to translate theoretical knowledge into practical actions in this area. Therefore, it is important to study the correlations among change, change management, and internal communication [20].

Referring to the above considerations, the main purpose of the article is to identify and evaluate the perceived impacts of selected factors related to internal communication in IT companies in Poland on the adaptation of innovation by employees at different stages of the innovation process. The structure of the remaining part of the article begins with a literature review on the introduction and adaptation of innovations. Next, selected internal communication factors that can potentially affect the adaptation of innovations are characterized. This is followed by a description of the research methods and the results of the statistical analysis and discussion. In the next part, conclusions, which are divided into scientific and practical, are presented, and they can be used as guidelines for management during the implementation of innovations. Finally, some limitations are signaled and opportunities for future research are presented.

\section{Literature Review}

Analysis of the available literature on organizational innovation indicates that open technologies and high-quality open resources and information systems are important determinants of its creation. Knowledge management is the most important part of innovation, as it constitutes a competitive advantage [21]. On the other hand, innovation adoption can be defined as the generation, development, and implementation of new initiatives or activities [22]. Dissemination and adoption of innovation is related to the growing interest in economics, market research, and sociology [23]. It is also concerned with deciding how best to use it in an organization [24]. The adaptation of innovations is of great importance for the survival of a firm [25] because the successful implementation of constantly evolving new technologies is a key determinant of organizational competitiveness [26]. 
In addition, firms adopt organizational innovations to achieve business benefits related to greater operational efficiency, quality control, learning, and market development [27]. The comprehensive benefits related to the implementation of organizational innovations mentioned here certainly encourage increases in knowledge about them by conducting diverse research in this field. They will contribute to the improvement of the whole process and will help to overcome employees' resistance against their introduction.

The study of innovation adaptation belongs to a subset of more general theories of technological evolution [28]. It is also considered within the framework of evolutionary economics. The evolution of knowledge and its use to create technological innovations are key components for increasing competition among technologies that are fighting to capture market share [29]. The success of innovations introduces results from complex dynamics that are characterized by different patterns [30]. The traditional approach to the assimilation of new technologies in organizations is a hierarchical approach that emphasizes top-down control. According to it, managers maintain control by adjusting the organizational reward system and involvement in all aspects of the assimilation process, both at the level of managerial activity and at the level of goal achievement [31].

The literature identifies several essential stages of innovation. The first begins with the organization realizing that there is a need. This is followed by the search for solutions, and then by the initial decision to try to introduce a solution. The final stage is the actual decision to try to continue implementing the innovative solution [32]. C. A. Voss's model seems to be an interesting one. It assumes that the realization of the introduction of an innovation includes three stages: the evaluation stage, installation and launch (whose manifestations are so-called technical success), and consolidation (which assumes business success). We can conclude from this that before adopting an innovation, organizations first evaluate it in terms of benefits and risks. Then, the innovation is implemented, reviewed, and further adapted to organizational realities [33]. Experts in the literature also refer to E. M. Rogers's model [28,34], which distinguishes three stages of innovation in the IT industry. The first one consists of the so-called initial adoption (which is based on activities related to the recognition of needs, gaining knowledge about innovations, forming attitudes towards them, and making proposals in this area). The second stage is related to the adoption decision (and consists in the evaluation of the proposal from the technical, financial, and strategic points of view, along with the allocation of resources for its acquisition and implementation). The final stage, on the other hand, the implementation, includes preparing the organization to use the innovation, conducting a trial implementation of the innovation, its acceptance by users, and further actual use [35]. Based on this model, for the purposes of the research, it was assumed that the innovation process is divided into three stages: the innovation initiation stage, stage of the decision to adopt the innovation, and innovation implementation stage.

It should also be mentioned that information and communication technologies used by the IT industry are themselves a product of innovation, they can serve as a tool for disseminating information about innovation, and their adaptation significantly affects the process of research and development [36]. It is worth noting here that an enterprise must express so-called organizational readiness, which is defined as the availability of certain organizational resources to adapt new IT innovations, including human resources and financial and infrastructural assets. It is also characterized as the organization's absorptive capacity or ability to use innovative and existing knowledge that has been shown to be related to the adaptation of innovation [37].

When analyzing the issue of innovation adaptation, it is worth paying attention to the proper estimation of costs. The costs of both domestic innovation and introduction of foreign innovations are estimated on the basis of innovation, production, and trade data [38]. The tools that improve the value of new products and services should also not be overlooked. The Business Model of Innovation can become helpful here. It improves not only the value of products or services, but also delivers these offerings to customers [39]. It is also one of the ways to bind together organizational processes, structures, and strategies [40]. 
Innovation implementation is a process with an uncertain outcome. What is certain, however, is that its initiation can positively or negatively affect the competitiveness of a company [41].

The literature emphasizes that effective internal communication channels are crucial for innovation implementation [42]. Therefore, it is necessary to consider the factors of internal communication that can potentially affect the adaptation of innovations, thus eliminating the emerging barriers. Indeed, internal communication manifests itself in the ability of employees to provide feedback to the leader(s) on emerging issues [43].

The first factor is internal communication training. The knowledge gained from such training can be very important because it is helpful in the proactive problem solving of potential participants [44]. Coaching can be an effective tool for improving internal communication. Its overarching goal is to improve organizational potential through the development of individual employees and entire teams. The path leading to this goal is described by the characteristics of the coaching process. It is based on authenticity, partnership, trust, and responsibility of both parties [45].

Another factor is good relationships with employees. The literature emphasizes that internal communication strengthens the linkage between supervisors and employees, which affects more effective articulation of values and goals that are priorities for the organization [46].

It is also very important to improve internal communication by adapting its tools. It is worth creating a list of all tools available and useful for a specific audience. This list can include items such as e-mail, newsletters, telephone, mail, and many others. It should be cross-checked to make sure it is appropriate for the specific target audience [47].

Further elements of internal communication are concerned with ensuring access to information, rapid flow of information, and sharing of knowledge within the team/organization. This is possible, among other things, through knowledge management systems. These are designed and maintained by professionals in organizations to support knowledge-based processes, such as knowledge acquisition, knowledge creation, knowledge sharing, knowledge dissemination, and continuous access to knowledge [48]. Additional benefits of a well-functioning knowledge management system can also include increased employee loyalty and faster decision making [49].

It is worth noting here that organizations that have their own way of sharing knowledge effectively, as well as continuously acquiring new information resources, often gain a sustainable competitive advantage [50]. Given the importance of sharing employees' knowledge with the continuous development of information and communication technologies, more and more organizations are gradually changing their ways of knowledge management and work, moving from interpersonal to virtual relationships [51]. This makes it possible to obtain key (essential) information for the organization in large amounts.

A clear and effective way of communicating information is also of great importance in internal communication. It has been shown that the way organizations communicate with their employees during a change program has a significant impact on the success of the entire process and also on the individual commitment and morale of the employees [52].

Another factor identified for the purpose of the study concerns supervisors' communication skills. Speaking, listening, and the ability to effectively understand both verbal and nonverbal meanings are among the most important skills that managers must possess in order to foster or maintain effective communication in organizations, which is essential for both performance improvement and business growth [53].

The communication skills of a company's other employees are equally important. Companies that recognize the correlation between employee engagement and business success will look for ways to create said engagement. One way is to provide interpersonal communication training [54]. It is important for employees to understand and value communication approaches that differ from their own style and to adapt their communication style to the other person. Listening skills are also crucial and have a significant impact on the efficient transmission and receipt of information in the workplace [55]. 
The last internal communication factor analyzed is the flattening of the organizational structure. Studies on European companies have shown that companies are increasingly flattening their organizational structures, using project-based structures and increasing decentralization in both operational and strategic decision making [56].

Moreover, when making changes in the human resource management system, it is recommended to pay special attention to the flexibility of the organizational structure by reducing formalization, delegating decision-making authority, flattening the organizational structure, and enabling employees to actively participate in processes related to knowledge management [57]. It is also worth noting that there is a relationship between organizational structure and the use of information and communication technologies [58,59]. The adoption of ICTs is more likely to be seen in decentralized companies where a liberal management style prevails [60]. G. H. Huber indicates that during the flattening of managerial hierarchy, the need for information intermediaries is reduced. According to him, the role of middle managers as information supervisors becomes redundant [61].

In summary, for the purpose of this research, 12 internal communication factors were identified as potentially influencing innovation adoption at three stages of innovation, as shown in Figure 1.

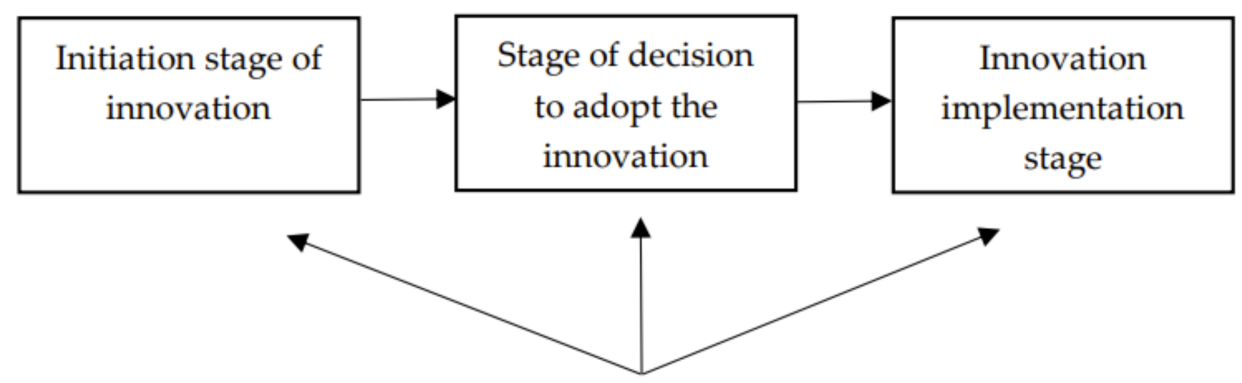

\begin{tabular}{|c|}
\hline $\begin{array}{c}\text { Training and meetings on improving internal } \\
\text { communication }\end{array}$ \\
\hline Good relations among employees \\
\hline Improving internal communication by adapting \\
its tools \\
\hline Ensuring access to information \\
\hline Ensuring fast flow of information \\
\hline Obtaining necessary information \\
\hline Sharing knowledge within the \\
team/organization \\
\hline Obtaining a large amount of information \\
\hline Clear and effective way of communicating \\
\hline Communication skills of superiors \\
\hline Communication skills of other employees in the \\
company \\
\hline Flattening of the organizational structure \\
\hline
\end{tabular}

Figure 1. Selected internal communication factors potentially influencing innovation adoption.

\section{Materials and Methods}

This paper focuses on the analysis of selected factors related to internal communication in a company, which may affect the adaptation of innovations during their implementation in the IT industry in Poland. The examples of divisions of the process of innovation into different stages, cited in the literature, mostly generalize the influence of factors affecting the adaptation of innovation on the whole process of its implementation [62]. This article is a continuation of research [19] that discussed organizational culture factors affecting 
innovation adaptation. In this approach, it was assumed that the factors related to internal communication in the company used in the questionnaire differently affect the adaptation of innovations at different stages of the innovation process, which became the basis for the implementation of empirical research.

The research was conducted in the IT industry due to the fact that it has become one of the most profitable and dynamically developing areas of the economy on a global scale. One of the main reasons for this intensive development is the significant demand for IT services, in the broad sense of the word. Modern IT companies compete with each other in terms of creating a new product or service for potential customers [63].

The aim of the research was to identify and evaluate the influence of selected factors related to internal communication on innovation adoption by IT industry employees in Poland, taking into account different stages of innovation implementation. The hypothesis of the study was that selected internal communication factors affect innovation adaptation to different degrees at different stages of the innovation introduction process.

The study combined expert opinions and a literature analysis with a diagnostic survey (questionnaire) and a statistical analysis. The author's survey questionnaire made it possible to examine the respondents' opinions on the impacts of 12 factors related to internal communication in the company on innovation adaptation. Selected factors were determined on the basis of the literature analysis, opinions of panel participants (experts), and the pilot studies conducted.

In order to determine the reliability of the questionnaire "The process of adaptation and perception of innovation", Cronbach's alpha internal consistency coefficients were calculated for the group of internal communication factors. It turned out that at each stage, they had very good reliability: innovation initiation stage: alpha $=0.87$; innovation adoption decision stage: alpha $=0.85$; innovation implementation stage: alpha $=0.84$.

The statistical analysis was aimed at evaluating individual internal communication factors in terms of their influence on the adoption of the innovation at different stages of the innovation process. The study compared the different stages of the innovation implementation process in terms of perceiving any influence on innovation adaptation of individual factors, rating the shape of this influence (on a scale of 1-5) on innovation adaptation (in the case of perceiving the influence of a particular factor), and the average rating of the shape of influence on innovation adaptation given to internal communication factors.

The database was organized and checked for completeness before analysis. The following statistical tests and methods were used to examine the selected relationships:

- Multidimensional cluster analysis was used to identify subgroups of factors that were more similar to objects in a given cluster compared to objects in other clusters.

- In this method, the distance between two clusters was determined by the distance between the two closest objects (nearest neighbors) belonging to different clusters [64].

- The objects (factors) were grouped in two ways: using the hierarchical agglomeration method and non-hierarchical clustering using the k-means method. The first method allowed the generation of hierarchically ordered clusters, which could be presented as a hierarchical tree (dendrogram) that presented the distances between objects. The second method moved the objects between the indicated number of clusters in order to minimize the intra-group variability and maximize the inter-group variability [64].

- The Mann-Whitney U test was used to compare two groups in terms of quotient or ordinal variables [65]. Glass's rank two-series correlation coefficient was used as a measure of the effect size [66].

- Spearman's rank order correlation was used to test the relationship between two variables of a quotient and/or ordinal nature [65].

The level of significance of the statistical results obtained was taken as $p<0.05$. Statistical calculations were performed using the Statistica v.13.3 PL statistical package from Tulsa, OK, USA. The survey was conducted from January to June 2019. The final number of respondents qualified for the study was 400 people (72 women and 328 men) from 310 IT companies in Poland. To calculate the minimum sample size, the formula [67] 
determining the sample size for qualitative characteristics was used. The size of the general population was 200,254 [68] employees working in 1370 [69] IT companies. On this basis, the minimum sample size was calculated to be 300 companies and 383 employees.

\section{Results and Discussion}

The first part of the analysis compared the different stages of the innovation process in terms of the perception by the surveyed employees of IT companies in Poland of the impacts of factors related to internal communication on the adaptation of innovation. For this purpose, a Mann-Whitney rank-sum test analysis was performed. The results of this analysis indicated that 7 out of 12 factors related to internal communication were statistically significantly different at different stages in terms of perceived impact on innovation adaptation. These factors were: training and meetings on improving internal communication $(\mathrm{Z}=5.18$; $\left.p<0.001 ; r_{g}=0.28\right)$; good relationships among employees $\left(Z=6.85 ; p<0.001 ; r_{g}=0.36\right)$; improving internal communication by adapting its tools $\left(Z=5.85 ; p<0.001 ; r_{\mathrm{g}}=0.32\right)$; sharing knowledge within the team or organization $\left(Z=-8.49 ; p<0.001 ; r_{g}=-0.55\right)$; communication skills of supervisors $\left(Z=-4.87 ; p<0.001 ; r_{g}=-0.26\right)$ and other company employees $\left(Z=-5.81 ; p<0.001 ; r_{g}=-0.30\right)$; flattening the organizational structure $(Z=7.26 ; p<0.001$; $\left.r_{g}=0.48\right)$. For each of the above-mentioned factors, their influence was perceived significantly less frequently at the innovation initiation stage in the context of innovation adaptation (compared to the other stages). This means that the surveyed respondents noticed the influence of the above-mentioned factors less frequently at the first stage of innovation initiation, while they did so much more frequently at the later stages of the above-mentioned process in terms of the final adaptation of innovation in the company. It should be added that the majority of the respondents noticed the influence of each factor related to internal communication on innovation adaptation at each stage of innovation implementation. Detailed data on this subject are presented in Table 1.

Table 1. Comparison of stages of the innovation process in terms of respondents' perception of the influence of various factors related to internal communication on its adaptation.

\begin{tabular}{|c|c|c|c|c|c|c|c|c|c|}
\hline & & \multicolumn{2}{|c|}{$\begin{array}{l}\text { Innovation } \\
\text { Initiation } \\
\text { Stage }\end{array}$} & \multicolumn{2}{|c|}{$\begin{array}{l}\text { Stage of } \\
\text { Decision to } \\
\text { Adopt the } \\
\text { Innovation }\end{array}$} & \multicolumn{2}{|c|}{$\begin{array}{c}\text { Innovation } \\
\text { Implementation } \\
\text { Stage }\end{array}$} & \multirow[t]{2}{*}{$\begin{array}{l}\text { Mann- } \\
\text { Whitney } \\
\text { U Test }\end{array}$} & \multirow[t]{2}{*}{$\begin{array}{l}\text { rg of } \\
\text { Glass }\end{array}$} \\
\hline & & $\mathbf{N}$ & $\%$ & $\mathbf{N}$ & $\%$ & $\mathbf{N}$ & $\%$ & & \\
\hline \multirow{2}{*}{$\begin{array}{l}\text { Training and meetings on improving } \\
\text { internal communication }\end{array}$} & Yes & 327 & $81.75 \%$ & 370 & $92.50 \%$ & 375 & $93.75 \%$ & \multirow{2}{*}{$\begin{array}{l}Z=5.18 \\
p<0.001\end{array}$} & \multirow{2}{*}{0.28} \\
\hline & No & 73 & $18.25 \%$ & 30 & $7.50 \%$ & 25 & $6.25 \%$ & & \\
\hline \multirow{2}{*}{ Good relations among employees } & Yes & 311 & $77.75 \%$ & 372 & $93.00 \%$ & 377 & $94.25 \%$ & \multirow{2}{*}{$\begin{array}{l}Z=6.85 \\
p<0.001\end{array}$} & \multirow{2}{*}{0.36} \\
\hline & No & 89 & $22.25 \%$ & 28 & $7.00 \%$ & 23 & $5.75 \%$ & & \\
\hline \multirow{2}{*}{$\begin{array}{l}\text { Improving internal communication by } \\
\text { adapting its tools }\end{array}$} & Yes & 322 & $80.50 \%$ & 375 & $93.75 \%$ & 376 & $94.00 \%$ & \multirow{2}{*}{$\begin{array}{l}Z=5.85 \\
p<0.001\end{array}$} & \multirow{2}{*}{0.32} \\
\hline & No & 78 & $19.50 \%$ & 25 & $6.25 \%$ & 24 & $6.00 \%$ & & \\
\hline \multirow{2}{*}{ Ensuring access to information } & Yes & 389 & $97.25 \%$ & 386 & $96.50 \%$ & 392 & $98.00 \%$ & \multirow{2}{*}{$\begin{array}{l}Z=0.61 \\
p=0.541\end{array}$} & \multirow{2}{*}{0.06} \\
\hline & No & 11 & $2.75 \%$ & 14 & $3.50 \%$ & 8 & $2.00 \%$ & & \\
\hline \multirow{2}{*}{ Ensuring fast flow of information } & Yes & 387 & $96.75 \%$ & 386 & $96.50 \%$ & 391 & $97.75 \%$ & \multirow{2}{*}{$\begin{array}{l}Z=0.78 \\
p=0.435\end{array}$} & \multirow{2}{*}{0.08} \\
\hline & No & 13 & $3.25 \%$ & 14 & $3.50 \%$ & 9 & $2.25 \%$ & & \\
\hline \multirow{2}{*}{ Obtaining necessary information } & Yes & 394 & $98.50 \%$ & 390 & $97.50 \%$ & 393 & $98.25 \%$ & \multirow{2}{*}{$\begin{array}{c}Z=-0.24 \\
p=0.808\end{array}$} & \multirow{2}{*}{-0.03} \\
\hline & No & 6 & $1.50 \%$ & 10 & $2.50 \%$ & 7 & $1.75 \%$ & & \\
\hline \multirow{2}{*}{$\begin{array}{l}\text { Sharing knowledge within the } \\
\text { team/organization }\end{array}$} & Yes & 331 & $82.75 \%$ & 389 & $97.25 \%$ & 396 & $99.00 \%$ & \multirow{2}{*}{$\begin{array}{c}Z=-8.49 \\
p<0.001\end{array}$} & \multirow{2}{*}{-0.55} \\
\hline & No & 69 & $17.25 \%$ & 11 & $2.75 \%$ & 4 & $1.00 \%$ & & \\
\hline
\end{tabular}


Table 1. Cont.

\begin{tabular}{|c|c|c|c|c|c|c|c|c|c|}
\hline & & \multicolumn{2}{|c|}{$\begin{array}{l}\text { Innovation } \\
\text { Initiation } \\
\text { Stage }\end{array}$} & \multicolumn{2}{|c|}{$\begin{array}{l}\text { Stage of } \\
\text { Decision to } \\
\text { Adopt the } \\
\text { Innovation }\end{array}$} & \multicolumn{2}{|c|}{$\begin{array}{l}\text { Innovation } \\
\text { Implementation } \\
\text { Stage }\end{array}$} & \multirow[t]{2}{*}{$\begin{array}{c}\text { Mann- } \\
\text { Whitney } \\
\text { U Test }\end{array}$} & \multirow[t]{2}{*}{$\begin{array}{l}\text { rg of } \\
\text { Glass }\end{array}$} \\
\hline & & $\mathbf{N}$ & $\%$ & $\mathbf{N}$ & $\%$ & $\mathbf{N}$ & $\%$ & & \\
\hline \multirow{2}{*}{ Obtaining a large amount of information } & Yes & 386 & $96.50 \%$ & 388 & $97.00 \%$ & 392 & $98.00 \%$ & \multirow{2}{*}{$\begin{array}{c}Z=1.2 \\
p=0.228\end{array}$} & \multirow{2}{*}{0.12} \\
\hline & No & 14 & $3.50 \%$ & 12 & $3.00 \%$ & 8 & $2.00 \%$ & & \\
\hline \multirow{2}{*}{ Clear and effective way of communicating } & Yes & 390 & $97.50 \%$ & 394 & $98.50 \%$ & 395 & $98.75 \%$ & \multirow{2}{*}{$\begin{array}{l}Z=1.27 \\
p=0.204\end{array}$} & \multirow{2}{*}{0.16} \\
\hline & No & 10 & $2.50 \%$ & 6 & $1.50 \%$ & 5 & $1.25 \%$ & & \\
\hline \multirow{2}{*}{ Communication skills of superiors } & Yes & 325 & $81.25 \%$ & 370 & $92.50 \%$ & 371 & $92.75 \%$ & \multirow{2}{*}{$\begin{aligned} \mathrm{Z} & =-4.87 \\
p & <0.001\end{aligned}$} & \multirow{2}{*}{-0.26} \\
\hline & No & 75 & $18.75 \%$ & 30 & $7.50 \%$ & 29 & $7.25 \%$ & & \\
\hline \multirow{2}{*}{$\begin{array}{l}\text { Communication skills of other employees in } \\
\text { the company }\end{array}$} & Yes & 316 & $79.00 \%$ & 365 & $91.25 \%$ & 373 & $93.25 \%$ & \multirow{2}{*}{$\begin{aligned} \mathrm{Z} & =-5.81 \\
p & <0.001\end{aligned}$} & \multirow{2}{*}{-0.30} \\
\hline & No & 84 & $21.00 \%$ & 35 & $8.75 \%$ & 27 & $6.75 \%$ & & \\
\hline \multirow{2}{*}{ Flattening of the organizational structure } & Yes & 336 & $84.00 \%$ & 391 & $97.75 \%$ & 391 & $97.75 \%$ & \multirow{2}{*}{$\begin{array}{l}Z=7.26 \\
p<0.001\end{array}$} & \multirow{2}{*}{0.48} \\
\hline & No & 64 & $16.00 \%$ & 9 & $2.25 \%$ & 9 & $2.25 \%$ & & \\
\hline
\end{tabular}

Then, the evaluations of the shapes of the influences of factors related to internal communication in the company were compared in terms of the adaptation of innovation at different stages of the innovation process. For this purpose, Spearman's rank order correlation analysis was applied. In the case of factors related to internal communication, statistically significant differences were noted between the above-mentioned stages in terms of the evaluation of 5 out of 12 factors. It turned out that the more advanced the stage of innovation introduction was, the greater role in its adoption was attributed to factors such as: improving internal communication by adjusting its tools $(\mathrm{R}=0.07$; $\mathrm{t}(\mathrm{N}-2)=2.28 ; p<0$. 05); knowledge sharing within the team or organization $(\mathrm{R}=0.1$; $\mathrm{t}(\mathrm{N}-2)=3.33 ; p<0.001)$; communication skills of superiors $(\mathrm{R}=0.07 ; \mathrm{t}(\mathrm{N}-2)=2.3 ; p<0.05)$; other company employees $(\mathrm{R}=0.12 ; \mathrm{t}(\mathrm{N}-2)=4.04 ; p<0.001)$. On the other hand, the role of flattening the organizational structure $(\mathrm{R}=0.07 ; \mathrm{t}(\mathrm{N}-2)=2.46 ; p<0.05)$ at the first stage of innovation, i.e., the innovation initiation stage, was attributed as lower $(\mathrm{M}=3.61 ; \mathrm{SD}=1.02)$ than at further stages, i.e., the decision to adopt the innovation $(\mathrm{M}=3.81 ; \mathrm{SD}=1.06)$ and its implementation $(\mathrm{M}=3.8 ; \mathrm{SD}=1.05)$. The other factors were not statistically significantly different across stages in terms of evaluating the shapes of their influences on innovation adoption. Detailed results are presented in Table 2.

Table 2. Comparison of stages of the innovation process implementation in terms of respondents assessment of the shapes of the influences of individual factors related to internal communication on innovation adaptation.

\begin{tabular}{|c|c|c|c|c|c|c|c|c|}
\hline & & \multicolumn{6}{|c|}{ Descriptive Statistics } & \multirow{3}{*}{$\begin{array}{l}\text { Spearman } \\
\text { Rank Order } \\
\text { Correlation }\end{array}$} \\
\hline & & \multirow{2}{*}{$\begin{array}{l}\text { Mean } \pm \text { Stand } \\
\text { Deviation }\end{array}$} & \multirow{2}{*}{$\begin{array}{c}\text { Median; } \\
(\text { Q25-Q75) }\end{array}$} & \multirow{2}{*}{ Min.-Max. } & \multicolumn{2}{|c|}{$\begin{array}{l}\text { Confidence } \\
\text { Interval }\end{array}$} & \multirow{2}{*}{$\begin{array}{l}\text { Stand. } \\
\text { Error }\end{array}$} & \\
\hline & & & & & $-95 \%$ & $+95 \%$ & & \\
\hline \multirow{3}{*}{$\begin{array}{l}\text { Training and } \\
\text { meetings on } \\
\text { improving } \\
\text { internal com- } \\
\text { munication }\end{array}$} & Initiation stage of innovation & $3.95 \pm 0.8$ & $4(4-4)$ & $1-5$ & 3.86 & 4.04 & 0.04 & \multirow{3}{*}{$\begin{array}{c}\mathrm{R}=0.04 ; \\
\mathrm{t}(\mathrm{N}-2)=1.29 \\
p=0.198\end{array}$} \\
\hline & $\begin{array}{l}\text { The stage of making the decision } \\
\text { to adopt innovations }\end{array}$ & $3.85 \pm 0.84$ & $4(3-4)$ & $1-5$ & 3.76 & 3.93 & 0.04 & \\
\hline & Innovation implementation stage & $3.99 \pm 0.87$ & $4(4-5)$ & $1-5$ & 3.90 & 4.08 & 0.05 & \\
\hline
\end{tabular}


Table 2. Cont.

\begin{tabular}{|c|c|c|c|c|c|c|c|c|}
\hline & & \multicolumn{6}{|c|}{ Descriptive Statistics } & \multirow{3}{*}{$\begin{array}{l}\text { Spearman } \\
\text { Rank Order } \\
\text { Correlation }\end{array}$} \\
\hline & & \multirow{2}{*}{$\begin{array}{l}\text { Mean } \pm \text { Stand } \\
\text { Deviation }\end{array}$} & \multirow{2}{*}{$\begin{array}{l}\text { Median; } \\
\text { (Q25-Q75) }\end{array}$} & \multirow{2}{*}{ Min.-Max. } & \multicolumn{2}{|c|}{$\begin{array}{l}\text { Confidence } \\
\text { Interval }\end{array}$} & \multirow{2}{*}{$\begin{array}{l}\text { Stand. } \\
\text { Error }\end{array}$} & \\
\hline & & & & & $-95 \%$ & $+95 \%$ & & \\
\hline \multirow{3}{*}{$\begin{array}{c}\text { Good relations } \\
\text { among } \\
\text { employees }\end{array}$} & Initiation stage of innovation & $4.1 \pm 0.81$ & $4(4-5)$ & $1-5$ & 4.01 & 4.19 & 0.05 & \multirow{3}{*}{$\begin{array}{c}\mathrm{R}=0.05 \\
\mathrm{t}(\mathrm{N}-2)=1.53 \\
p=0.126\end{array}$} \\
\hline & $\begin{array}{l}\text { The stage of making the decision } \\
\text { to adopt innovations }\end{array}$ & $4.03 \pm 0.81$ & $4(4-5)$ & $1-5$ & 3.95 & 4.11 & 0.04 & \\
\hline & Innovation implementation stage & $4.18 \pm 0.81$ & $4(4-5)$ & $1-5$ & 4.09 & 4.26 & 0.04 & \\
\hline \multirow{3}{*}{$\begin{array}{c}\text { Improving } \\
\text { internal } \\
\text { communication } \\
\text { by adapting its } \\
\text { tools }\end{array}$} & Initiation stage of innovation & $3.92 \pm 0.78$ & $4(3-4)$ & $1-5$ & 3.84 & 4.01 & 0.04 & \multirow{3}{*}{$\begin{array}{c}\mathrm{R}=0.07 \\
\mathrm{t}(\mathrm{N}-2)=2.28 \\
\quad p<0.05\end{array}$} \\
\hline & $\begin{array}{c}\text { The stage of making the decision } \\
\text { to adopt innovations }\end{array}$ & $3.97 \pm 0.85$ & $4(3-5)$ & $1-5$ & 3.88 & 4.05 & 0.04 & \\
\hline & Innovation implementation stage & $4.04 \pm 0.86$ & $4(4-5)$ & $1-5$ & 3.95 & 4.13 & 0.04 & \\
\hline \multirow{3}{*}{$\begin{array}{l}\text { Ensuring access } \\
\text { to information }\end{array}$} & Initiation stage of innovation & $3.93 \pm 1.08$ & $3(3-5)$ & $1-5$ & 3.82 & 4.03 & 0.05 & \multirow{3}{*}{$\begin{array}{c}\mathrm{R}=-0.02 ; \\
\mathrm{t}(\mathrm{N}-2)=-0.56 \\
\quad p=0.578\end{array}$} \\
\hline & $\begin{array}{l}\text { The stage of making the decision } \\
\text { to adopt innovations }\end{array}$ & $3.86 \pm 1.04$ & $3(3-5)$ & $1-5$ & 3.76 & 3.97 & 0.05 & \\
\hline & Innovation implementation stage & $3.88 \pm 1.06$ & $3(3-5)$ & $1-5$ & 3.78 & 3.99 & 0.05 & \\
\hline \multirow{3}{*}{$\begin{array}{l}\text { Ensuring fast } \\
\text { flow of } \\
\text { information }\end{array}$} & Initiation stage of innovation & $4.23 \pm 0.86$ & $4(4-5)$ & $1-5$ & 4.15 & 4.32 & 0.04 & \multirow{3}{*}{$\begin{array}{c}\mathrm{R}=0.05 \\
\mathrm{t}(\mathrm{N}-2)=1.66 \\
\quad p<0.097\end{array}$} \\
\hline & $\begin{array}{c}\text { The stage of making the decision } \\
\text { to adopt innovations }\end{array}$ & $4.26 \pm 0.88$ & $4(4-5)$ & $1-5$ & 4.17 & 4.35 & 0.04 & \\
\hline & Innovation implementation stage & $4.32 \pm 0.84$ & $5(4-5)$ & $1-5$ & 4.24 & 4.41 & 0.04 & \\
\hline \multirow{3}{*}{$\begin{array}{l}\text { Obtaining } \\
\text { necessary } \\
\text { information }\end{array}$} & Initiation stage of innovation & $4.23 \pm 0.92$ & $4(4-5)$ & $1-5$ & 4.13 & 4.32 & 0.05 & \multirow{3}{*}{$\begin{array}{c}\mathrm{R}=0.03 \\
\mathrm{t}(\mathrm{N}-2)=0.91 \\
\quad p=0.365\end{array}$} \\
\hline & $\begin{array}{l}\text { The stage of making the decision } \\
\text { to adopt innovations }\end{array}$ & $4.26 \pm 0.91$ & $5(4-5)$ & $1-5$ & 4.17 & 4.35 & 0.05 & \\
\hline & Innovation implementation stage & $4.29 \pm 0.88$ & $5(4-5)$ & $1-5$ & 4.20 & 4.38 & 0.04 & \\
\hline \multirow{3}{*}{$\begin{array}{l}\text { Sharing } \\
\text { knowledge } \\
\text { within } \\
\text { the team/ } \\
\text { organization }\end{array}$} & Initiation stage of innovation & $4.09 \pm 0.91$ & $4(4-5)$ & $1-5$ & 3.99 & 4.19 & 0.05 & \multirow{3}{*}{$\begin{array}{c}\mathrm{R}=0.1 \\
\mathrm{t}(\mathrm{N}-2)=3.33 \\
p<0.001\end{array}$} \\
\hline & $\begin{array}{l}\text { The stage of making the decision } \\
\text { to adopt innovations }\end{array}$ & $4.11 \pm 0.77$ & $4(4-5)$ & $1-5$ & 4.03 & 4.18 & 0.04 & \\
\hline & Innovation implementation stage & $4.28 \pm 0.86$ & $4(4-5)$ & $1-5$ & 4.20 & 4.37 & 0.04 & \\
\hline \multirow{3}{*}{$\begin{array}{l}\text { Obtaining a } \\
\text { large amount of } \\
\text { information }\end{array}$} & Initiation stage of innovation & $3.37 \pm 1.24$ & $3(2-4)$ & $1-5$ & 3.25 & 3.50 & 0.06 & \multirow{3}{*}{$\begin{array}{c}\mathrm{R}=0.01 \\
\mathrm{t}(\mathrm{N}-2)=0.43 \\
\quad p=0.669\end{array}$} \\
\hline & $\begin{array}{l}\text { The stage of making the decision } \\
\text { to adopt innovations }\end{array}$ & $3.41 \pm 1.2$ & $4(2-4)$ & $1-5$ & 3.30 & 3.53 & 0.06 & \\
\hline & Innovation implementation stage & $3.41 \pm 1.24$ & $4(2-5)$ & $1-5$ & 3.29 & 3.54 & 0.06 & \\
\hline \multirow{3}{*}{$\begin{array}{c}\text { Communicating } \\
\text { clearly and } \\
\text { effectively }\end{array}$} & Initiation stage of innovation & $4.34 \pm 0.78$ & $5(4-5)$ & $2-5$ & 4.26 & 4.42 & 0.04 & \multirow{3}{*}{$\begin{array}{c}\mathrm{R}=0.04 \\
\mathrm{t}(\mathrm{N}-2)=1.5 \\
p=0.133\end{array}$} \\
\hline & $\begin{array}{l}\text { The stage of making the decision } \\
\text { to adopt innovations }\end{array}$ & $4.35 \pm 0.78$ & $5(4-5)$ & $2-5$ & 4.27 & 4.43 & 0.04 & \\
\hline & Innovation implementation stage & $4.41 \pm 0.8$ & $5(4-5)$ & $2-5$ & 4.33 & 4.48 & 0.04 & \\
\hline \multirow{3}{*}{$\begin{array}{l}\text { Communication } \\
\text { skills of } \\
\text { superiors }\end{array}$} & Initiation stage of innovation & $4.17 \pm 0.93$ & $4(4-5)$ & $1-5$ & 4.07 & 4.27 & 0.05 & \multirow{3}{*}{$\begin{array}{c}\mathrm{R}=0.07 \\
\mathrm{t}(\mathrm{N}-2)=2.3 \\
p<0.05\end{array}$} \\
\hline & $\begin{array}{l}\text { The stage of making the decision } \\
\text { to adopt innovations }\end{array}$ & $4.23 \pm 0.79$ & $4(4-5)$ & $1-5$ & 4.15 & 4.31 & 0.04 & \\
\hline & Innovation implementation stage & $4.32 \pm 0.86$ & $5(4-5)$ & $1-5$ & 4.23 & 4.41 & 0.04 & \\
\hline \multirow{3}{*}{$\begin{array}{l}\text { Communication } \\
\text { skills of other } \\
\text { employees in } \\
\text { the company }\end{array}$} & Initiation stage of innovation & $3.93 \pm 0.9$ & $4(3-5)$ & $1-5$ & 3.83 & 4.03 & 0.05 & \multirow{3}{*}{$\begin{array}{c}\mathrm{R}=0.12 \\
\mathrm{t}(\mathrm{N}-2)=4.04 \\
p<0.001\end{array}$} \\
\hline & $\begin{array}{l}\text { The stage of making the decision } \\
\text { to adopt innovations }\end{array}$ & $3.96 \pm 0.83$ & $4(4-5)$ & $1-5$ & 3.87 & 4.04 & 0.04 & \\
\hline & Innovation implementation stage & $4.19 \pm 0.8$ & $4(4-5)$ & $1-5$ & 4.11 & 4.27 & 0.04 & \\
\hline & Initiation stage of innovation & $3.61 \pm 1.02$ & $4(3-4)$ & $1-5$ & 3.50 & 3.72 & 0.06 & \\
\hline $\begin{array}{l}\text { Flattening of the } \\
\text { organizational } \\
\text { structure }\end{array}$ & $\begin{array}{l}\text { The stage of making the decision } \\
\text { to adopt innovations }\end{array}$ & $3.81 \pm 1.06$ & $4(3-5)$ & $1-5$ & 3.71 & 3.92 & 0.05 & $\begin{array}{c}\mathrm{R}=0.07 \\
\mathrm{t}(\mathrm{N}-2)=2.46\end{array}$ \\
\hline & Innovation implementation stage & $3.8 \pm 1.05$ & $4(3-5)$ & $1-5$ & 3.69 & 3.90 & 0.05 & \\
\hline
\end{tabular}


Taking into account the results of the average ratings of the influence of individual internal communication factors on innovation adaptation, the differences between the different stages of innovation were verified using Spearman's rank order correlation. This analysis revealed that respondents attributed a smaller role in innovation adoption to internal communication at the innovation initiation $(\mathrm{M}=4 ; \mathrm{SD}=0.56)$ and innovation adoption decision $(\mathrm{M}=4 ; \mathrm{SD}=0.56)$ stages than at the final innovation implementation stage $(M=4.07 ; \mathrm{SD}=0.58)$, and these differences were statistically significant $(\mathrm{R}=0.06$; $\mathrm{t}(\mathrm{N}-2)=2.1 ; p<0.05)$.

In the next step, similarly rated internal communication factors at different stages of innovation were identified using multivariate cluster analysis. The cluster analysis using the agglomeration method revealed that there were four clusters concerning internal communication at the innovation initiation stage, three of which were single-element factors, such as: providing access to information; obtaining a large amount of information; flattening the organizational structure. On the other hand, the remaining factors concerning internal communication were similar in terms of their influence ratings on the adaptation of innovations at the first stage, i.e., training and meetings on improving internal communication, good relations between employees, improving internal communication by adjusting its tools, ensuring fast flow of information, sharing knowledge within the team or organization, clear and effective way of communicating information, communication skills of superiors, obtaining necessary information, and communication skills of other employees of the company. It should be added here that among the above-mentioned factors, improving internal communication by adapting its tools and ensuring a quick flow of information, as well as a clear and effective way of communicating information and communication skills of superiors, were the most similar to each other. The following dendrogram (Figure 2) shows the visualization of the identified clusters.

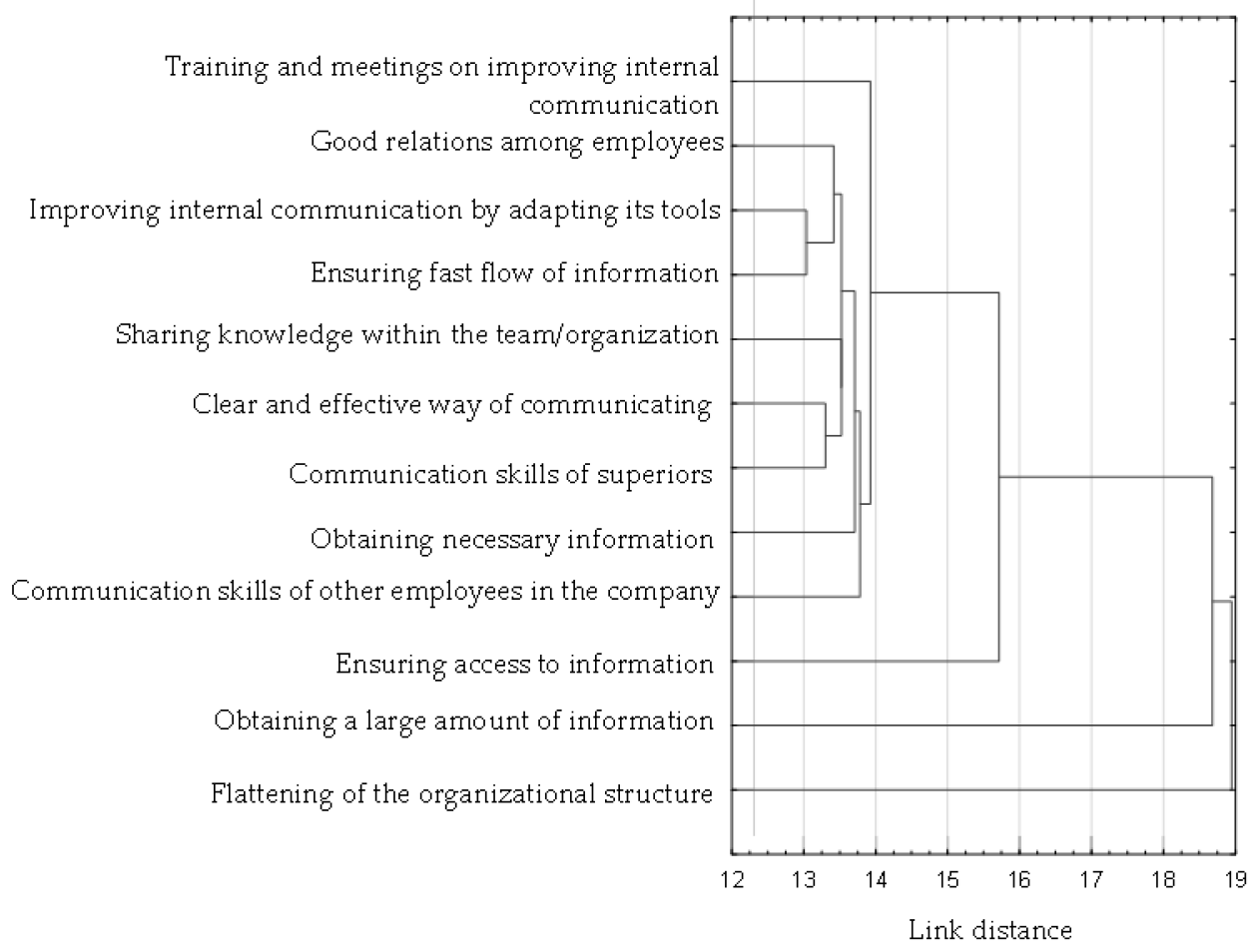

Figure 2. Dendrogram obtained for the analyzed factors related to internal communication in terms of their influence on the adaptation of innovation in its initiation stage (results of cluster analysis using agglomeration).

The results of the non-hierarchical feature clustering method, the so-called k-means clustering, fully agreed with those obtained by the agglomeration method. Thus, factors 
related to internal communication, such as providing access to information, obtaining a large amount of information, and flattening the organizational structure, were less similar to the others and were also single-element clusters. In contrast, the other factors were similarly rated in terms of their impacts on innovation adoption in the first stage of the innovation process. Descriptive statistics of the individual clusters indicated that the smallest role was attributed to the three aforementioned single-element clusters, i.e., obtaining a lot of information $(M=3.37 ; S D=1.24)$, flattening the organizational structure $(M=3.61$; $\mathrm{SD}=1.02)$, and providing access to information $(\mathrm{M}=3.93 ; \mathrm{SD}=1.08)$. On the other hand, the other factors constituting elements of one cluster were rated the highest in terms of their impact on innovation adoption in the innovation initiation stage $(M=4.12 ; S D=0.87)$. This means that the respondents considered factors such as training and meetings on improving internal communication, good relations among employees, improving internal communication by adjusting its tools, ensuring fast flow of information, obtaining necessary information, sharing knowledge within the team/organization, clear and effective way of communicating information, and communication skills of superiors and other employees of the company as equally important at the innovation initiation stage for its adoption. Table 3 presents detailed results.

Table 3. Cluster elements for the analyzed factors related to internal communication in terms of their influence on innovation adaptation at the stage of its initiation (results of cluster analysis using k-means clustering).

\begin{tabular}{|c|c|c|c|c|c|c|c|c|}
\hline & \multirow{3}{*}{ Elements of Individual Clusters } & \multirow{3}{*}{ Distance } & \multicolumn{6}{|c|}{$\begin{array}{l}\text { Descriptive Statistics of Influence Shape Ratings of Factors } \\
\text { Included in Each Cluster }\end{array}$} \\
\hline & & & \multirow{2}{*}{$\begin{array}{c}\text { Mean } \pm \\
\text { Standard } \\
\text { Deviation }\end{array}$} & \multirow{2}{*}{$\begin{array}{l}\text { Median } \\
(Q 25-Q 75)\end{array}$} & \multirow{2}{*}{ Min.-Max. } & \multicolumn{2}{|c|}{$\begin{array}{l}\text { Confidence } \\
\text { Interval }\end{array}$} & \multirow{2}{*}{$\begin{array}{l}\text { Stand. } \\
\text { Error }\end{array}$} \\
\hline & & & & & & $-95 \%$ & $+95 \%$ & \\
\hline Cluster no. 1 & Obtaining a large amount of information & 0.0000 & $3.37 \pm 1.24$ & $3(2-4.25)$ & $1-5$ & 3.25 & 3.50 & 0.06 \\
\hline Cluster no. 2 & Ensuring access to information & 0.0000 & $3.93 \pm 1.08$ & $3(3-5)$ & $1-5$ & 3.82 & 4.03 & 0.05 \\
\hline \multirow{9}{*}{ Cluster no. 3} & $\begin{array}{c}\text { Training and meetings on improving internal } \\
\text { communication }\end{array}$ & 0.6447 & \multirow{9}{*}{$4.12 \pm 0.87$} & \multirow{9}{*}{$4(4-5)$} & \multirow{9}{*}{$1-5$} & \multirow{9}{*}{4.09} & \multirow{9}{*}{4.15} & \multirow{9}{*}{0.02} \\
\hline & Good relations among employees & 0.5804 & & & & & & \\
\hline & $\begin{array}{l}\text { Improving internal communication by } \\
\text { adapting its tools }\end{array}$ & 0.6016 & & & & & & \\
\hline & Ensuring fast flow of information & 0.5684 & & & & & & \\
\hline & Obtaining necessary information & 0.6228 & & & & & & \\
\hline & $\begin{array}{l}\text { Sharing knowledge within the } \\
\text { team/organization }\end{array}$ & 0.6052 & & & & & & \\
\hline & Clear and effective way of communicating & 0.5852 & & & & & & \\
\hline & Communication skills of superiors & 0.6200 & & & & & & \\
\hline & $\begin{array}{l}\text { Communication skills of other employees in } \\
\text { the company }\end{array}$ & 0.6352 & & & & & & \\
\hline Cluster no. 4 & Flattening of the organizational structure & 0.0000 & $3.61 \pm 1.02$ & $4(3-4)$ & $1-5$ & 3.50 & 3.72 & 0.06 \\
\hline
\end{tabular}

At the stage of the decision to adopt the innovation, multidimensional cluster analysis using the agglomeration method showed that the factors related to internal communication that were most similar to each other and, thus, formed a single cluster were: training and meetings on improving internal communication; good relations among employees; ensuring a fast flow of information; clear and effective way of communicating information; obtaining necessary information; communication skills of superiors; communication skills of other employees of the company; sharing knowledge within the team or organization; improving internal communication by adjusting its tools. Among the above-mentioned factors, there were two groups that were even more similar in terms of assessing their impacts on the adaptation of the innovation at the above-mentioned stage of its implementation, i.e., 
the first group related to the flow of information (ensuring a fast flow of information, a clear and effective way of communicating information, and obtaining the necessary information), and the second group related to communication skills (of superiors and other employees of the company). The other factors related to internal communication (i.e., providing access to information, flattening the organizational structure, and obtaining a large amount of information) were less similar in terms of the above-mentioned evaluation and were single-element clusters. The dendrogram below (Figure 3) provides a visualization of the identified clusters.

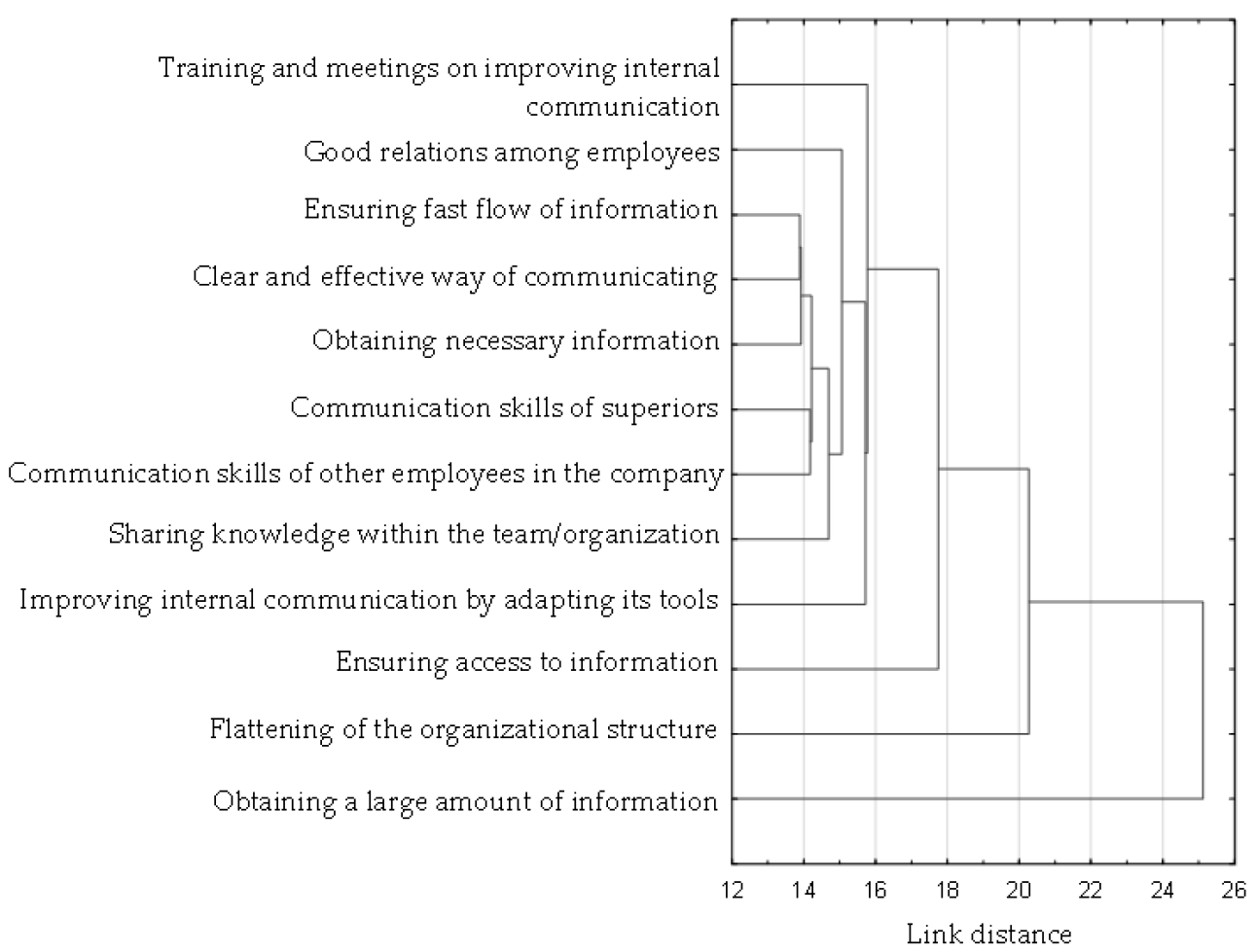

Figure 3. Dendrogram obtained for the analyzed factors related to internal communication in terms of their influence on the adaptation of the innovation in the adoption decision stage (results of cluster analysis using agglomeration).

Clustering using the k-means method revealed clusters of factors related to internal communication that were fully consistent with those obtained using the agglomeration method. Importantly, these clusters also coincided with the factors identified for this group in relation to the innovation initiation stage. This means that at the stage of the decision to adopt the innovation, factors related to internal communication, such as providing access to information, obtaining a large amount of information, and flattening the organizational structure, were also less similar to the others and constituted single-element clusters. On the other hand, all other factors were similar in terms of the assessment of their impacts on innovation adaptation in the first stage of the innovation process. The analysis of the descriptive statistics of the individual clusters indicated that, as in the innovation initiation stage, the three aforementioned single-element clusters, i.e., obtaining a large amount of information $(\mathrm{M}=3.41$; $\mathrm{SD}=1.2)$, flattening the organizational structure $(\mathrm{M}=3.81 ; \mathrm{SD}=1.06)$, and providing access to information $(\mathrm{M}=3.84$; $\mathrm{SD}=1.04)$, were assigned the least importance in the next stage of innovation introduction. The remaining factors belonging to one cluster were the highest-rated group in terms of their influence on innovation adoption in the adoption decision stage $(\mathrm{M}=4.11$; $\mathrm{SD}=0.84)$. Respondents believed that factors such as training and meetings on improving internal communication, good relationships among employees, improving internal communication by adjusting its tools, ensuring fast flow of information, obtaining necessary information, sharing knowledge within the team or 
organization, clear and effective way of communicating information, and communication skills of supervisors and other employees of the company were equally important for the adoption of the innovation at the decision stage. Table 4 shows the detailed results.

Table 4. Cluster elements for the analyzed factors related to internal communication in terms of their influence on the adaptation of the innovation at the stage of decision to adopt it (results of cluster analysis using k-means clustering).

\begin{tabular}{|c|c|c|c|c|c|c|c|c|}
\hline & \multirow{3}{*}{ Elements of Individual Clusters } & \multirow{3}{*}{ Distance } & \multicolumn{6}{|c|}{$\begin{array}{c}\text { Descriptive Statistics of Influence Shape Ratings of Factors } \\
\text { Included in Each Cluster }\end{array}$} \\
\hline & & & \multirow{2}{*}{$\begin{array}{c}\text { Mean } \pm \\
\text { Standard } \\
\text { Deviation }\end{array}$} & \multirow{2}{*}{$\begin{array}{l}\text { Median } \\
(Q 25-Q 75)\end{array}$} & \multirow{2}{*}{ Min.-Max. } & \multicolumn{2}{|c|}{$\begin{array}{l}\text { Confidence } \\
\text { Interval }\end{array}$} & \multirow{2}{*}{$\begin{array}{l}\text { Stand. } \\
\text { Error }\end{array}$} \\
\hline & & & & & & $-95 \%$ & $+95 \%$ & \\
\hline Cluster no. 1 & Obtaining a large amount of information & 0.0000 & $3.41 \pm 1.2$ & $4(2-4)$ & $1-5$ & 3.30 & 3.53 & 0.06 \\
\hline \multirow{9}{*}{ Cluster no. 2} & $\begin{array}{l}\text { Training and meetings to improve internal } \\
\text { communication }\end{array}$ & 0.6812 & \multirow{9}{*}{$4.11 \pm 0.84$} & \multirow{9}{*}{$4(4-5)$} & \multirow{9}{*}{$1-5$} & \multirow{9}{*}{4.09} & \multirow{9}{*}{4.14} & \multirow{9}{*}{0.01} \\
\hline & Good relations among employees & 0.5580 & & & & & & \\
\hline & $\begin{array}{l}\text { Improving internal communication by } \\
\text { adapting its tools }\end{array}$ & 0.6481 & & & & & & \\
\hline & Ensuring fast flow of information & 0.6001 & & & & & & \\
\hline & Obtaining necessary information & 0.6287 & & & & & & \\
\hline & $\begin{array}{l}\text { Sharing knowledge within the } \\
\text { team/organization }\end{array}$ & 0.5715 & & & & & & \\
\hline & Clear and effective way of communicating & 0.5625 & & & & & & \\
\hline & Communication skills of superiors & 0.5936 & & & & & & \\
\hline & $\begin{array}{l}\text { Communication skills of other employees in } \\
\text { the company }\end{array}$ & 0.6140 & & & & & & \\
\hline Cluster no. 3 & Flattening the organizational structure & 0.0000 & $3.81 \pm 1.06$ & $4(3-5)$ & $1-5$ & 3.71 & 3.92 & 0.05 \\
\hline Cluster no. 4 & Ensuring access to information & 0.0000 & $3.86 \pm 1.04$ & $3(3-5)$ & $1-5$ & 3.76 & 3.97 & 0.05 \\
\hline
\end{tabular}

The multidimensional cluster analysis using the agglomerative method showed that, at the innovation implementation stage, a group of factors that included all of the same factors as in the previous two stages (i.e., training and meetings on improving internal communication, good relations among employees, ensuring fast flow of information, obtaining necessary information, clear and effective way of communicating information, sharing knowledge within the team or organization, communication skills of superiors, communication skills of other employees of the company, and improving internal communication by adjusting its tools) and, additionally, ensuring access to information had an equally significant impact in terms of adoption. The other two factors in the above-mentioned category (i.e., flattening the organizational structure and obtaining a large amount of information) were found in terms of their impact on innovation adaptation to be less similar to the above-mentioned group of factors (and, thus, their role in the respondents' evaluations was different from the other factors). The following dendrogram (Figure 4) illustrates the distances between the different clusters and the factors included in them.

The results obtained with the cluster analysis that included k-means clustering fully confirmed those obtained with the previous method. There was one large cluster consisting of 10 factors, and taking into account the values of their mean scores, which were the highest of all clusters $(\mathrm{M}=4.14 ; \mathrm{SD}=0.92)$, these factors were attributed a significantly greater role in the adoption of the innovation at the final stage of its introduction. The respondents attributed less influence to flattening the organizational structure $(\mathrm{M}=3.8 ; \mathrm{SD}=1.05)$, while the least influence, according to respondents, at the last stage of innovation adoption was obtaining a lot of information $(\mathrm{M}=3.41 ; \mathrm{SD}=1.24)$. Detailed results are presented in Table 5. 


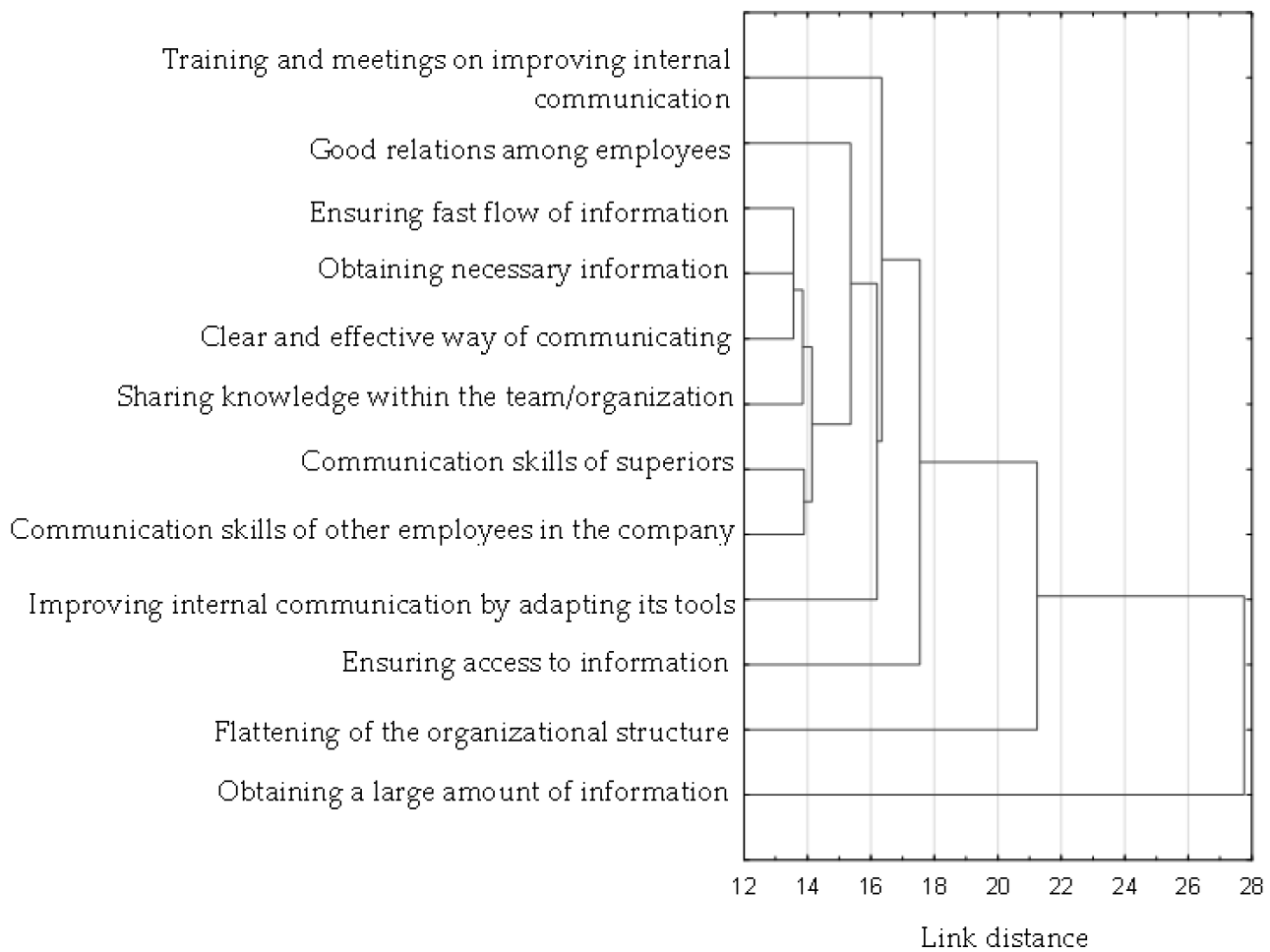

Figure 4. Dendrogram obtained for the analyzed factors related to internal communication in terms of their impact on innovation adaptation in the implementation stage (results of cluster analysis by agglomeration).

Table 5. Cluster elements for the analyzed factors related to internal communication in terms of their influence on innovation adaptation in the implementation stage (results of cluster analysis using k-means clustering).

\begin{tabular}{|c|c|c|c|c|c|c|c|c|}
\hline & \multirow{3}{*}{ Elements of Individual Clusters } & \multirow{3}{*}{ Distance } & \multicolumn{6}{|c|}{$\begin{array}{c}\text { Descriptive Statistics of Influence Shape Ratings of Factors } \\
\text { Included in Each Cluster }\end{array}$} \\
\hline & & & \multirow{2}{*}{$\begin{array}{c}\text { Mean } \pm \\
\text { Standard } \\
\text { Deviation }\end{array}$} & \multirow{2}{*}{$\begin{array}{l}\text { Median } \\
(\mathbf{Q} 25-Q 75)\end{array}$} & \multirow{2}{*}{ Min.-Max. } & \multicolumn{2}{|c|}{$\begin{array}{l}\text { Confidence } \\
\text { Interval }\end{array}$} & \multirow{2}{*}{$\begin{array}{l}\text { Stand } \\
\text { Error }\end{array}$} \\
\hline & & & & & & $-95 \%$ & $+95 \%$ & \\
\hline Cluster no. 1 & Flattening the organizational structure & 0.0000 & $3.8 \pm 1.05$ & $4(3-5)$ & $1-5$ & 3.69 & 3.90 & 0.05 \\
\hline \multirow{10}{*}{ Cluster no. 2} & $\begin{array}{l}\text { Training and meetings to improve internal } \\
\text { communication }\end{array}$ & 0.6501 & \multirow{10}{*}{$4.14 \pm 0.92$} & \multirow{10}{*}{$4(4-5)$} & \multirow{10}{*}{$1-5$} & \multirow{10}{*}{4.11} & \multirow{10}{*}{4.17} & \multirow{10}{*}{0.01} \\
\hline & Good relations among employees & 0.6104 & & & & & & \\
\hline & $\begin{array}{l}\text { Improving internal communication by } \\
\text { adapting its tools }\end{array}$ & 0.6415 & & & & & & \\
\hline & Ensuring access to information & 0.7555 & & & & & & \\
\hline & Ensuring fast flow of information & 0.5412 & & & & & & \\
\hline & Obtaining necessary information & 0.5423 & & & & & & \\
\hline & $\begin{array}{l}\text { Sharing knowledge within the } \\
\text { team/organization }\end{array}$ & 0.5662 & & & & & & \\
\hline & Clear and effective way of communicating & 0.5541 & & & & & & \\
\hline & Communication skills of superiors & 0.5947 & & & & & & \\
\hline & $\begin{array}{l}\text { Communication skills of other employees in } \\
\text { the company }\end{array}$ & 0.6045 & & & & & & \\
\hline Cluster no. 3 & Obtaining a large amount of information & 0.0000 & $3.41 \pm 1.24$ & $4(2-5)$ & $1-5$ & 3.29 & 3.54 & 0.06 \\
\hline
\end{tabular}




\section{Conclusions}

The results from the research conducted here allow the indication of theoretical and practical conclusions. It turned out that all of the internal communication factors selected and discussed in the theoretical part [44-59] affect innovation adaptation to a greater or lesser extent. Comparing the obtained results to those of previous studies on innovation adaptation [19], it can be concluded that, as a group, internal communication factors have a greater positive impact on innovation adaptation than factors related to organizational culture.

The statistical analysis confirmed the hypothesis adopted in the article, i.e., the selected factors of internal communication have different influences on the adaptation of innovations at different stages of the process of their introduction. These include: training and meetings on improving internal communication; good relationships among employees; improving internal communication by adapting its tools; sharing knowledge within the team or organization; communication skills of superiors and other employees; flattening the organizational structure. For each of the above-mentioned factors, their influence was perceived significantly less frequently at the innovation initiation stage in the context of its adaptation (compared to the other stages).

Moreover, using Spearman's rank order correlation analysis, it turned out that the more advanced the stage of innovation initiation, the greater role in its adaptation was attributed to such factors as: improving internal communication by adjusting its tools; knowledge sharing within the team or organization; communication skills of superiors and other company employees. On the other hand, a smaller role was ascribed to flattening of the organizational structure at the first stage of innovation introduction, i.e., the innovation initiation stage, than at further stages, i.e., the decision to adopt an innovation and its implementation. The other factors did not differ statistically significantly across the stages in terms of assessing the shape of their influence on innovation adaptation. Thus, it can be concluded that the current flow of information about the innovative solutions implemented in the organization is very important, and it significantly affects their adaptation by employees.

Practical conclusions lead to the formulation of guidelines that may be helpful while introducing innovations in IT companies in Poland. At the innovation initiation stage, the following elements played the most important role in its adaptation: training and meetings on improving internal communication; good relations among employees; improving internal communication by adjusting its tools; ensuring fast information flow; obtaining necessary information; sharing knowledge within the team/organization; clear and effective way of communicating; communication skills of superiors and other company employees. On this basis, it can be concluded that ongoing communication about introduced innovations-using an efficient communication system corresponding to the needs of employees - is the key to success. A wide range of information and communication technologies can be helpful in this respect after the employees have been trained in this field. This aforementioned shift from interpersonal to virtual relationships is very beneficial, especially in the era of the COVID-19 pandemic, as it affects not only the quality of the message, but also the safety of the organization's members [51].

At the stage of deciding to adopt an innovation, the same factors as those indicated above were of great importance to the respondents. It is also worth emphasizing that the element that determines the efficient course of this stage is good relations among employees. Building relationships is a long-term process based on trust management and the creation of a coherent system of values, which will be convergent with the system of values professed by the organization. The values declared (e.g., in the code of ethics) must be identical to the values professed.

The respondents were also exceptionally unanimous in their answers concerning the last stage, i.e., implementation of innovations. Apart from the above elements, they pointed to access to information. It is necessary, especially in the era of pandemics, to break the resistance of employees to changes. Thanks to this, employees will not only not be afraid of changes, but will also accept them in a relatively short time. 
The studies presented in this article have some limitations. Firstly, they were conducted only in Poland and, secondly, only in the IT industry; thirdly, only selected internal communication factors were taken into account. Confirmation of the different impacts of internal communication factors on the adaptation of innovation at different stages of its implementation opens up the possibility for further research on this issue in both different industries and different countries. There is also a possibility of developing a comprehensive model of introducing innovations, which could help in effective implementation of innovations. The final result of this activity could be the creation of an interactive internet platform where companies from different industries can share their experiences with the implementation and adaptation of innovations based on so-called good practices.

Author Contributions: Conceptualization, J.O. and A.K.; methodology, J.O.; software, J.O.; validation, J.O.; formal analysis, J.O. and A.K.; writing-original draft preparation, J.O. and A.K.; writingreview and editing, J.O. and A.K.; visualization, J.O.; supervision, J.O. All authors have read and agreed to the published version of the manuscript.

Funding: This research was funded by the Department of Applied Social Sciences of the Faculty of Organization and Management of the Silesian University of Technology, grant number 2021: 13/020/BK21/0062.

Institutional Review Board Statement: Not applicable.

Informed Consent Statement: Not applicable.

Data Availability Statement: Not applicable.

Conflicts of Interest: The authors declare no conflict of interest.

\section{References}

1. Clemente-Suárez, V.J.; Navarro-Jiménez, E.; Moreno-Luna, L.; Saavedra-Serrano, M.C.; Jimenez, M.; Simón, J.A.; Tornero-Aguilera, J.F. The Impact of the COVID-19 Pandemic on Social, Health, and Economy. Sustainability 2021, 13, 6314. [CrossRef]

2. Chen, J.; Huang, J.; Su, W.; Štreimikienè, D.; Baležentis, T. The challenges of Covid-19 policies for sustainable development of business: Evidence from service industries. Technol. Soc. 2021, 66, 101643. [CrossRef] [PubMed]

3. Dessouky, N.F.E.; Al-Ghareeb, A. Human Resource Management and Organizational Resilience in The Era of Covid-19: Theoretical Insights, Challenges and Implications. In Proceedings of the 2020 Second International Sustainability and Resilience Conference: Technology and Innovation in Building Designs, Sakheer, Bahrain, 11-12 November 2020; pp. 1-6. [CrossRef]

4. Roberts, R.; Flin, R.; Millar, D.; Corradi, L. Psychological factors influencing technology adoption: A case study from the oil and gas industry. Technovation 2021, 102, 102219. [CrossRef]

5. Brodny, J.; Tutak, M.; Michalak, M. A Data Warehouse as an Indispensable Tool to Determine the Effectiveness of the Use of the Longwall Shearer. In Beyond Databases, Architectures and Structures. Towards Efficient Solutions for Data Analysis and Knowledge Representation; Kozielski, S., Mrozek, D., Kasprowski, P., Małysiak-Mrozek, B., Kostrzewa, D., Eds.; Springer: Cham, Switzerland, 2017; pp. 453-465. [CrossRef]

6. Kogabayev, T.; Maziliauskas, A. The definition and classification of innovation. Holistica 2017, 8, 59-72. [CrossRef]

7. Zastempowski, M.; Cyfert, S. Impact of entrepreneur's gender on innovation activities. The perspective of small businesses. PLOS ONE 2021, 16, e0258661. [CrossRef]

8. Frobisher, P. Strategic model of innovation. Int. J. Syst. Innov. 2021, 6, 19-29. [CrossRef]

9. Santiago, M.; Morales, C. Innovation as recovery strategy for SMEs in emerging economies during the Covid-19 pandemic. Res. Int. Bus. Financ. 2021, 57, 101396. [CrossRef]

10. Fonseca, T.; Faria, P.; Lima, F. Human capital and innovation: The importance of the optimal organizational task structure. Res. Policy 2019, 48, 616-627. [CrossRef]

11. Katz, J.S. What is a complex innovation system? PLoS ONE 2016, 11, e0156150. [CrossRef]

12. McPhillips, M.; Licznerska, M. Open Innovation Competence for a Future-Proof Workforce: A Comparative Study from Four European Universities. J. Appl. Electron. Commer. Res. 2021, 16, 2442-2457. [CrossRef]

13. Suhada, T.A.; Ford, J.A.; Verreynne, M.L.; Indulska, M. Motivating individuals to contribute to firms' non-pecuniary open innovation goals. Technovation 2021, 102, 102233. [CrossRef]

14. Kuzior, A.; Lyulyov, O.; Pimonenko, T.; Kwilinski, A.; Krawczyk, D. Post-Industrial Tourism as a Driver of Sustainable Development. Sustainability 2021, 13, 8145. [CrossRef]

15. Kuzior, A. Polskie i niemieckie doświadczenia w projektowaniu i wdrażaniu zrównoważonego rozwoju. Polish and German Experiences in Planning and Implementation of Sustainable Development. Probl. Ekorozw. 2010, 5, 81-89. 
16. Thomas, A.; Scandurra, G.; Carfora, A. Adoption of green innovations by SMEs: An investigation about the influence of stakeholders. Eur. J. Innov. Manag. 2021. [CrossRef]

17. Spieth, P.; Schneider, S. Business model innovativeness: Designing a formative measure for business model innovation. J. Bus. Econ. 2016, 86, 671-696. [CrossRef]

18. Linton, G. Innovativeness, risk-taking, and proactiveness in startups: A case study and conceptual development. J. Glob. Entrep. Res. 2019, 9, 20. [CrossRef]

19. Ober, J. Innovation adoption: Empirical analysis on the example of selected factors of organizational culture in the IT industry in Poland. Sustainability 2020, 12, 8630. [CrossRef]

20. Kitchen, P.J.; Daly, F. Internal communication during change management. Corp. Commun. Int. J. 2002, 7, 46-53. [CrossRef]

21. Rajapathirana, R.P.J.; Hui, Y. Relationship between innovation capability, innovation type, and firm performance. J. Innov. Knowl. 2018, 3, 44-55. [CrossRef]

22. Damanpour, F. Organizational Innovation: A Meta-Analysis of Effects of Determinants and Moderators. Acad. Manag. J. 1991, 34, 555-590. [CrossRef]

23. Sáenz-Royo, C.; Gracia-Lázaro, C.; Moreno, Y. The role of the Organization Structure in the Diffusion of Innovations. PLoS ONE 2015, 10, e0126076. [CrossRef]

24. Frambach, R.T.; Schillewaert, N. Organizational innovation adoption: A multi-level framework of determinants and opportunities for future research. J. Bus. Res. 2002, 55, 163-176. [CrossRef]

25. Oorschot, J.A.W.H.; Hofman, E.; Halman, J.I.M. A bibliometric review of the innovation adoption literature. Technol. Forecast. Soc. Chang. 2018, 134, 1-21. [CrossRef]

26. Makkonen, H.; Johnston, W.J.; Javalgi, R.G. A behavioral approach to organizational innovation adoption. J. Bus. Res. 2016, 69, 2480-2489. [CrossRef]

27. Arranz, N.; Arroyabe, M.F.; Li, J.; Arroyabe, J.C.F. An integrated model of organisational innovation and firm performance: Generation, persistence and complementarity. J. Bus. Res. 2019, 105, 270-282. [CrossRef]

28. Toufaily, E.; Zalan, T.; Dhaou, S.B. A framework of blockchain technology adoption: An investigation of challenges and expected value. Inf. Manag. 2021, 58, 103444. [CrossRef]

29. Miranda, L.C.M.; Lima, C.A.S. Technology substitution and innovation adoption: The cases of imaging and mobile communication markets. Technol. Forecast. Soc. Chang. 2013, 80, 1179-1193. [CrossRef]

30. Tacchella, A.; Napoletano, A.; Pietronero, L. The language of innovation. PLoS ONE 2020, 15, e0230107. [CrossRef]

31. Hasgall, A.; Ahituv, N. Implementing continuous adaptation to technology innovation in complex adaptive organizations. J. High Technol. Manag. Res. 2018, 29, 35-45. [CrossRef]

32. Damanpour, F.; Schneider, M. Phases of the Adoption of Innovation in Organizations: Effects of Environment, Organization and Top Managers. Br. J. Manag. 2006, 17, 215-236. [CrossRef]

33. Voss, C.A. Implementation: A key issue in manufacturing technology: The need for a field of study. Res. Policy 1988, 17, 55-63. [CrossRef]

34. Hameed, M.A.; Counsell, S.; Swift, S. A conceptual model for the process of IT innovation adoption in organizations. J. Eng. Technol. Manag. 2012, 29, 358-390. [CrossRef]

35. Rogers, E.M. Diffusion of Innovations; Free Press: New York, NY, USA, 2003.

36. Ejemeyovwi, J.O.; Osabuohien, E.S.; Bowale, E.I.K. ICT adoption, innovation and financial development in a digital world: Empirical analysis from Africa. Transnatl. Corp. Rev. 2021, 13, 16-31. [CrossRef]

37. Hameed, M.A.; Counsell, S.; Swift, S. A meta-analysis of relationships between organizational characteristics and IT innovation adoption in organizations. Inf. Manag. 2012, 49, 218-232. [CrossRef]

38. Santacreu, A.M. Innovation, diffusion, and trade: Theory and measurement. J. Monet. Econ. 2015, 75, 1-20. [CrossRef]

39. Keiningham, T.; Aksoy, L.; Bruce, H.L.; Cadet, F.; Clennell, N.; Hodgkinson, I.R.; Kearney, T. Customer experience driven business model innovation. J. Bus. Res. 2020, 116, 431-440. [CrossRef]

40. Moroz, P.W.; Gamble, E.N. Business model innovation as a window into adaptive tensions: Five paths on the B Corp journey. J. Bus. Res. 2021, 125, 672-683. [CrossRef]

41. Verena, J.; Spieth, T.; Heidenreich, S. Active innovation resistance: An empirical study on functional and psychological barriers to innovation adoption in different contexts. Ind. Mark. Manag. 2018, 71, 95-107. [CrossRef]

42. Zhai, Y.; Ding, Y.; Zhang, H. Innovation adoption: Broadcasting versus virality. J. Assoc. Inf. Sci. Technol. 2021, 72, 403-416. [CrossRef]

43. Jacobsen, C.B.; Salomonsen, H.H. Leadership strategies and internal communication in public organizations. Int. J. Public Sect. Manag. 2021, 34, 137-154. [CrossRef]

44. Besley, J.C.; Dudo, A.; Storksdieck, M. Scientists' views about communication training. J. Res. Sci. Teach. 2015, 52, 199-220. [CrossRef]

45. Kołodziejczak, M. Coaching Across Organizational Culture. Procedia Econ. Financ. 2015, 23, 329-334. [CrossRef]

46. Bergman, S. When communication professionals become trainers: A new role. J. Commun. Manag. 2020, 24, 85-102. [CrossRef]

47. Alexe, C.G.; Alexe, C.M.; Popescu, C.A.; Niculescu, C. Improving Internal Communication at The Company's Level. In International Conference on Management and Industrial Engineering; Niculescu Publishing House: Bucharest, Romania, 2011; pp. 248-256. 
48. Rowley, J.; Hartley, R. Organizing Knowledge. An introduction to Managing Access to Information; Routledge Taylor and Francis Group: London, UK; New York, NY, USA, 2017. [CrossRef]

49. Goh, C.; Hooper, V. Knowledge and information sharing in a closed information environment. J. Knowl. Manag. 2009, 13, 21-34. [CrossRef]

50. Israilidis, J.; Siachou, E.; Kelly, S. Why organizations fail to share knowledge: An empirical investigation and opportunities for improvement. Inf. Technol. People 2021, 34, 1513-1539. [CrossRef]

51. Chumg, H.-F.; Cooke, L.; Fry, J.; Hung, I.-H. Factors affecting knowledge sharing in the virtual organisation: Employees' sense of well-being as a mediating effect. Comput. Hum. Behav. 2015, 44, 70-80. [CrossRef]

52. Goodman, J.; Truss, C. The medium and the message: Communicating effectively during a major change initiative. J. Chang. Manag. 2004, 4, 217-228. [CrossRef]

53. Kalogiannidis, S. Impact of Effective Business Communication on Employee Performance. Eur. J. Bus. Manag. Res. 2020, 5, 1-6. [CrossRef]

54. Hynes, G.E. Improving Employees' Interpersonal Communication Competencies: A Qualitative Study. Bus. Commun. Q. 2012, 75, 466-475. [CrossRef]

55. Carnevale, A.P.; Smith, N. Workplace basics: The skills employees need and employers want. Hum. Resour. Dev. Int. 2013, 16, 491-501. [CrossRef]

56. Heracleous, L. Strategy and Organization: Realizing Strategic Management; Cambridge University Press: Cambridge, UK, 2003.

57. Lendzion, J.P. Human Resources Management in the System of Organizational Knowledge Management. Procedia Manuf. 2015, 3, 674-680. [CrossRef]

58. Kuzior, A.; Postrzednik-Lotko, K. Natural Language and Gettering of Information. In Sustainable Economic Development and Advancing Education Excellence in the Era of Global Pandemic; Proceedings of the 36th International Business Information Management Association Conference (IBIMA), Granada, Spain, 4-5 November 2020; Soliman, K.S., Ed.; International Business Information Management Association: Granada, Spain, 2020; pp. 13479-13486.

59. Zieliński, M.; Jonek-Kowalska, I. Does CSR Affect the Profitability and Valuation of Energy Companies? An Example from Poland. Energies 2021, 14, 3668. [CrossRef]

60. Čudanov, M.; Jaško, O.; Jevtić, M. Influence of information and communication technologies on decentralization of organizational structure. Comput. Sci. Inf. Syst. 2009, 6, 93-109. [CrossRef]

61. Huber, G.P. A Theory of the Effects of Advanced Information Technologies on Organizational Design, Intelligence, and Decision Making. Acad. Manag. Rev. 1990, 15, 47-71. [CrossRef]

62. Pichlak, M. Uwarunkowania procesu adaptacji innowacji w polskich organizacjach. Organ. I Kier. 2015, 2, 37-50.

63. Nazdrowicz, J. Wyzwania branży IT a kooperacja z uczelniami wyższymi w kontekście kształcenia zasobów ludzkich. Kwart. Nauk. Uczel. Vistula 2017, 1, 108-118.

64. Stanisz, A. Przystępny Kurs Statystyki z Zastosowaniem STATISTICA PL na Przykładach z Medycyny. Tom 3. Analizy Wielowymiarowe; StatSoft Polska Sp. z o.o.: Cracow, Poland, 2007.

65. Stanisz, A. Przystępny Kurs Statystyki z Zastosowaniem STATISTICA PL na Przykładach z Medycyny. Tom 1. Statystyki Podstawowe; StatSoft Polska Sp. z o.o.: Cracow, Poland, 2006.

66. Panczyk, M. Prezentacja Podstawy Biostatystyki 9a. Miary Wielkości Efektu. Available online: https://www.authorstream.com/ Presentation/panstudio-2620824-9a-miary-wielko-ci-efektu-dla-por-wna-dw-ch-grup/ (accessed on 12 October 2021).

67. Mynarski, S. Praktyczne Metody Analizy Danych Rynkowych i Marketingowych; Kantor Wydawniczy Zakamycze: Cracow, Poland, 2000.

68. Number of Employees in the IT Industry in Poland in 2017 (as of November 2018) Based on the Central Statistical Office (GUS) According to the Code pkd62 "Services Related to Software and Consulting in the Field of IT and Related Services" (Only Companies Declaring Employment of 10 People or More Were Taken into Account). Available online: http:/ / stat.gov.pl/obszary-tematyczne/rynek-pracy/pracujacy-zatrudnieni-wynagrodzenia-koszty-pracy/pracujacy-wgospodarce-narodowej-w-2017-roku,7,15.html (accessed on 25 November 2018).

69. Number of IT Companies in Poland in 2018 (as of November 2018) Based on the Central Statistical Office (GUS) According to the Code pkd62 "Services Related to Software and IT Consulting and Related Services" (Only Companies Declaring Employment of 10 People or More Were Taken into Account). Available online: https://stat.gov.pl/obszary-tematyczne/podmioty-gospodarczewyniki-finansowe/zmiany-strukturalne-grup-podmiotow / miesieczna-informacja-o-podmiotach-gospodarki-narodowej-wrejestrze-regon-pazdziernik-2018,4,16.html (accessed on 25 November 2018). 